\title{
Femtosecond laser-assisted anterior lamellar keratoplasty for the treatment of stromal corneal pathology
}

Yan Lu, Liping Yang, YiRui Ge, Xiangfei Chen and Zhenping Huang*

\begin{abstract}
Background: To describe the initial outcomes and safety of anterior lamellar keratoplasty (ALK) assisted by a femtosecond laser for stromal corneal pathology.

Methods: A non-comparative case series of 14 eyes (13 patients) with various stromal corneal diseases underwent ALK with a femtosecond laser. Femtosecond laser settings, technique, uncorrected visual acuity (UCVA), best-corrected visual acuity (BCVA), and endothelial cell density (ECD) were measured.

Results: All eyes were successfully treated without intraoperative complications. The UCVA improved in 11 eyes (78.6\%) compared with preoperative UCVA. The mean difference between preoperative and postoperative UCVA was a gain of 1.7 lines (range, unchanged to 6 lines). The BCVA improved in all eyes compared with preoperative levels. The mean difference between preoperative and postoperative BCVA was a gain of 2.4 lines (range, 1-8 lines). In 3 eyes, phototherapeutic keratectomy was performed. The mean reduction in endothelial cell density was $3.7 \%$ after a mean 7.3 months of follow-up. No graft rejection, infection, or epithelial ingrowth was found.

Conclusions: Femtosecond laser-assisted ALK improved UCVA and BCVA in patients with stromal corneal pathology. Our early results indicated that the femtosecond laser produced an effective and smooth dissection through opaque corneas even deeper corneal tissue.
\end{abstract}

Keywords: Femotosecond laser, Anterior lamellar keratoplasty, Corneal stromal pathology, Opacity

\section{Background}

Anterior lamellar keratoplasty (ALK) is a lamellar transplantation surgical technique used for the treatment of corneal diseases that does not affect the endothelium. The donor lamella is positioned directly on Descemet's membrane, preserving the recipient's endothelium and decreasing the risk of immunologic rejection $[1,2]$. This technique has been reported to treat stromal corneal pathology with a good endothelium such as keratoconus [3,4], postrefractive keratectasia [5], stromal dystrophies [6], and anterior corneal scars after trauma or keratitis $[7,8]$.

ALK can be performed manually, semi-mechanized with an automated microkeratome, or with an excimer laser [9]. However, these technologies can result in irregular stromal interface between the donor and recipient lamella

\footnotetext{
*Correspondence: huangzhenping1963@163.com

Department of Ophthalmology, Jinling Hospital, School of Medicine, Nanjing University, 305 East Zhongshan Road, Nanjing 210002, PR China
}

that could bring out stromal haze, irregular astigmatism, and loss of best-corrected visual acuity (BCVA).

Femtosecond laser assisted corneal surgery has gained more and more popular and could overcome those problems induced by traditional ALK. The purpose of this study was to report the visual outcomes following femtosecond laser-assisted ALK to treat the patients with stromal corneal diseases.

\section{Methods}

Patient data

Fourteen eyes of 13 patients (5 females and 8 males) aged 20 to 80 years with postkeratitis corneal leucoma, or posttraumatic corneal scarring, or anterior corneal stromal dystrophy receiving ALK were recruited for the study between March 2012 and May 2013 by a single surgeon (Z.H.) at the Department of Ophthalmology, Jinling Hospital, PR China. All patients were informed

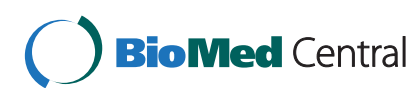


appropriately about the procedures and risks of surgery, and signed an informed consent statement before the operation. The study was approved by the medical ethics committee of Jinling Hospital and adhered to the tenets of the Declaration of Helsinki.

All treated eyes were examined preoperatively and postoperatively. We have measured the uncorrected visual acuity (UCVA) and BCVA with use of a standard Snellen chart. Anterior segment optical coherence tomography (Carl Zeiss Meditec, Jena, Germany) was used for all patients to estimate corneal scarring depth in the recipient cornea (Figure 1). Slit lamp examination, corneal topography, and $50-\mathrm{MHz}$ ultrasound corneal pachymetry were also performed. Eyes with a total corneal scarring thickness more than $450 \mu \mathrm{m}$, and those with evidence of ongoing bacterial infection, were excluded from the study.

\section{Surgical technique}

The eyeballs of donors were collected and evaluated within 12 hours after death. To provide the graft from donor, the whole eyeball was placed in the eyeball fixation (Figure 2) (designed and made by the authors, patent number ZL 2012 20199036.3) for receiving the laser treatment. Regarding the size of graft, we have evaluated the opaque area to decide the cutting diameter, and there will be $0.2 \mathrm{~mm}$ smaller of recipient corneal lenticule than the donor graft. For the thickness, we have measured the depth of the donative and recipient corneas to calculate the average value of corneal thickness between ultrasound corneal pachymtry and anterior segment optical coherence tomography in the position of thinnest corneal, moreover there will be up to $20 \%$ extra thickness added to the donor lenticule to adjust for donor tissue swelling.

The donative and recipient corneal lamella were cut with $500-\mathrm{kHz}$ VisuMax ${ }^{\oplus}$ femtosecond laser (Carl Zeiss
Meditec AG, Jena, Germany) with the following parameters: $455 \pm 59.71 \mu \mathrm{m}$ (range, $350-540 \mu \mathrm{m}$ ) of donor lenticule; 7.74 $\pm 0.15 \mathrm{~mm}$ (range, 7.6-8.1 mm) of donor diameter; 220-240 nJ for leticule cut; and 220-240 nJ for side cut; The track distance and spot distance were $1.9 \mu \mathrm{m}$ in the graft and $1.5 \mu \mathrm{m}$ on the graft side, respectively, with a $90^{\circ}$ side cut angle.

For recipient cornea, $4 \%$ ossibuprocaine eye drop was instilled three times before a cone for single use was fixed the corneoscleral junction.

A recipient corneal lenticule was produced with following parameters: the lenticule thickness was $374.29 \pm$ $80.07 \mu \mathrm{m}$ (range, 190-500 $\mu \mathrm{m}$ ), with $7.56 \pm 0.12 \mathrm{~mm}$ (range, $7.4-7.8 \mathrm{~m}$ ) of and $97.49 \pm 47.94 \mu \mathrm{m}$ of residual stromal bed.

After femtosecond laser procedure, the patient was transferred to the operating room. The recipient corneal button was then lifted and replaced with the donor lenticule (Figure 3B) on the recipient residual corneal stromal bed (Figure 3D) with a technique of continuous or 16 interrupted suture under retrobulbar anesthesia with light sedation.

Systemic administration of intravenous antibiotics and corticosteroids was used once a day for 3 days. Tobramycin dexamethasone and ofloxacin eye drops were applied 6 times and 4 times a day respectively for 2 weeks. Then, flumetholon and cyclosporine A eye drops were instilled three times per day for 3 months to prevent graft rejection.

Data of the end follow-up visit of each patient were recorded and selected for analysis.

\section{Results}

There were no intraoperative or postoperative complications and all patients were uneventful in lamellar separation in this study. Corneal stromal pathologies resulted from postkeratitis corneal leucoma in 8 patients, posttraumatic
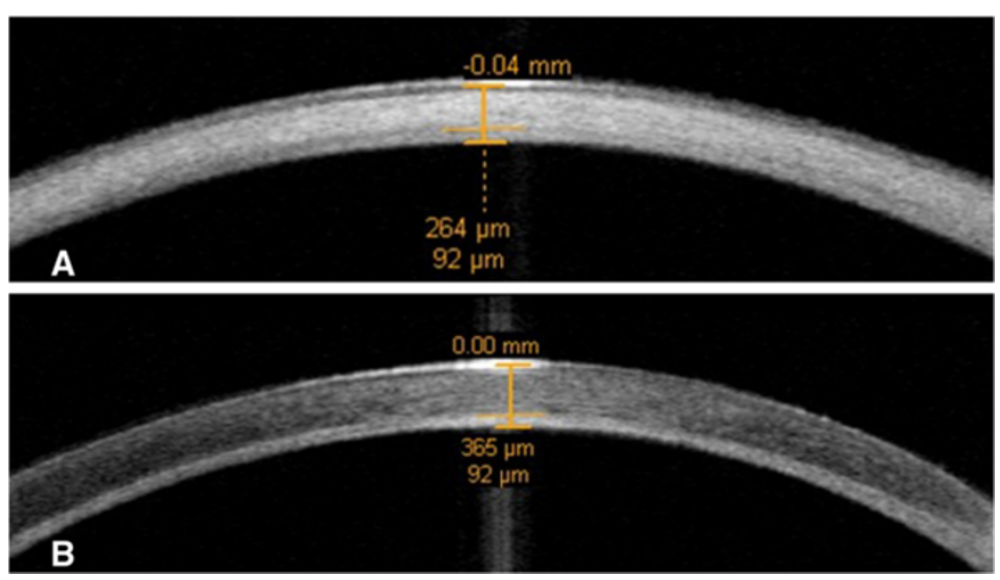

Figure 1 Represented the anterior segment optical coherence tomography to evaluate the thickness of corneal scarring (A) preoperatively (B) 2 months after femtosecond laser-assisted deep anterior lamellar keratoplasty. 


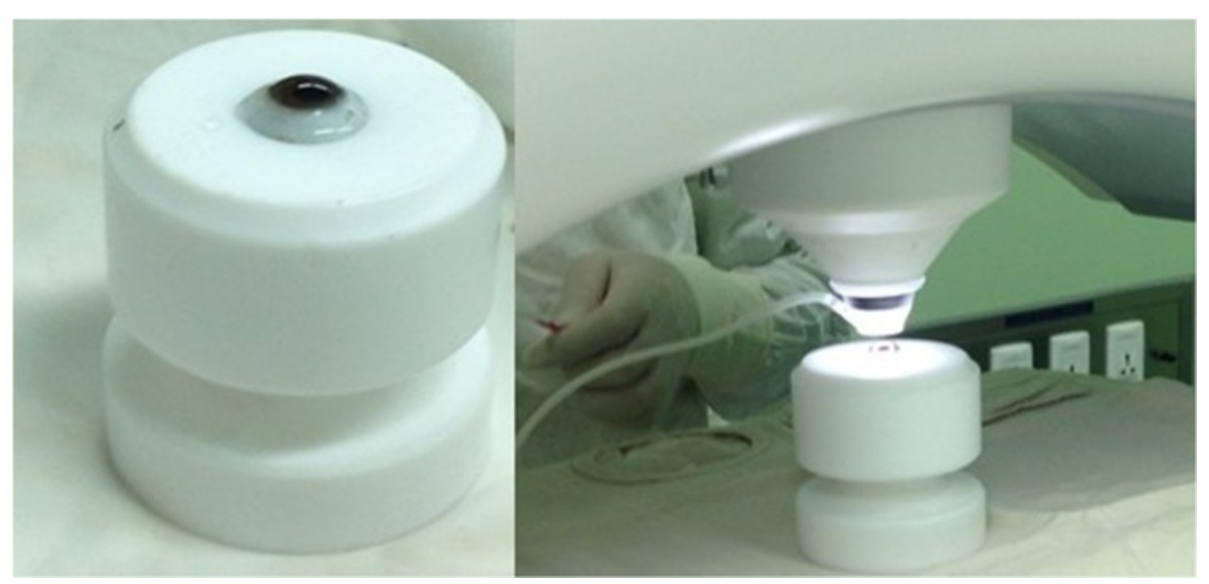

Figure 2 The eyeball fixation (left). The femtosecond laser was used to cut the donor cornea (right).
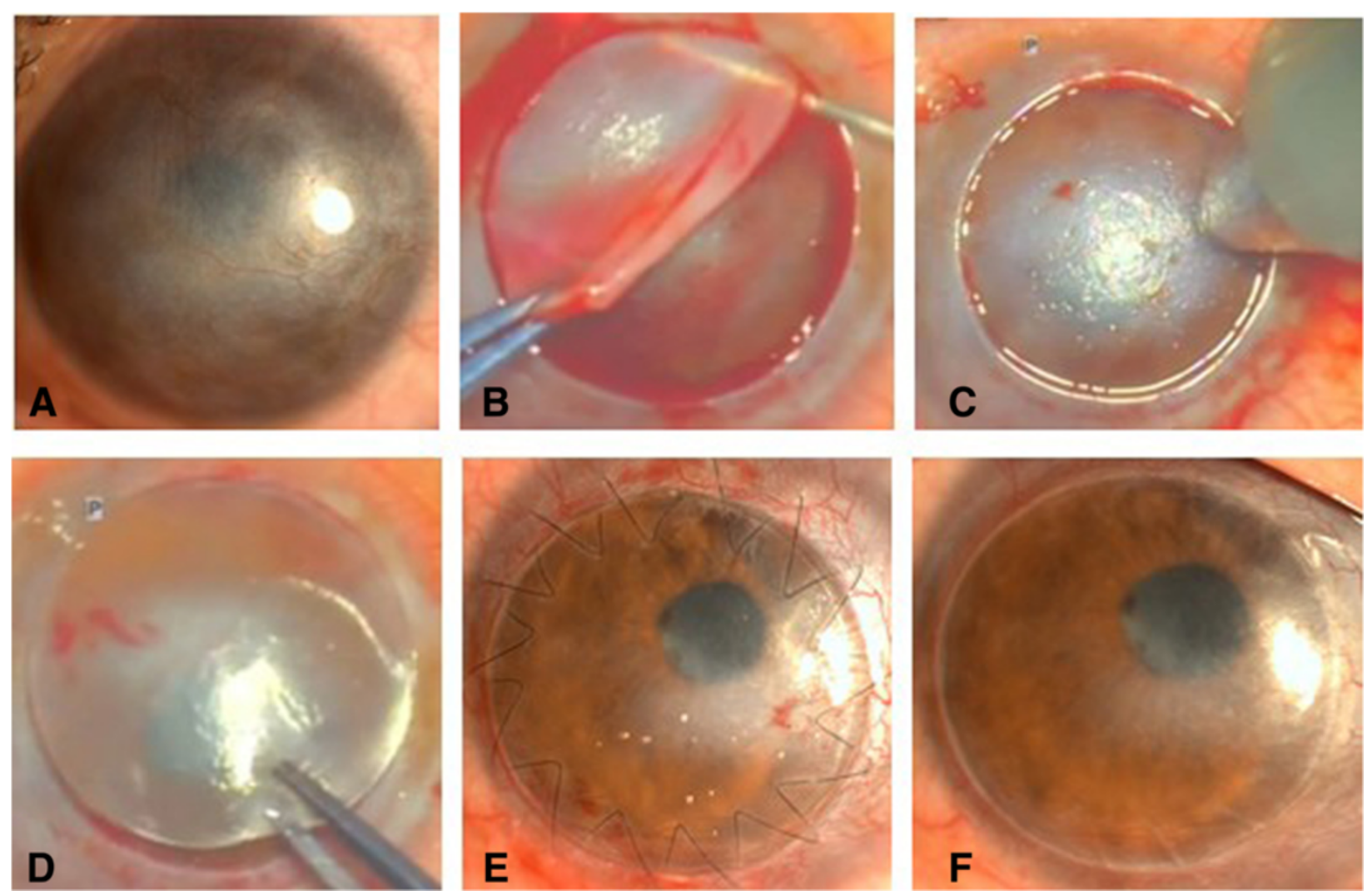

Figure 3 Preoperatively and postoperatively slit lamp photographs of a patient with posttraumatic corneal scar and the surgery procedure. A: Represented the slit lamp photographs for the patient with posttraumatic corneal scar and neovascularization preoperatively. B: lift the separated recipient corneal tissue after the treatment with femtosecond laser. C: Depth of the residual corneal scaring measured with ultrasound corneal pachymetry before phototherapeutic keratectomy. D: Place donor corneal tissue over the recipient corneal stromal bed. E: Represented the corneal graft with continuous sutures 5 days after femtosecond laser-assisted deep anterior lamellar keratoplasty. F: The cornea with removed sutured at 1.25 months after surgery. 
corneal scarring (Figure 3A) in 1 patient, and anterior stromal corneal dystrophy in 5 patients. The preoperative UCVA ranged from counting fingers (CF) to 0.2 , and preoperative BCVA ranged from CF to 0.25 (Table 1). The mean preoperative endothelial cell density (ECD) was $2120.0 \pm 589.73$ cells $/ \mathrm{mm}^{2}$ (range, $1100-3290.1$ cells $/ \mathrm{mm}^{2}$ ).

Maximum follow-up was 14 months (mean, $7.29 \pm$ 3.82 months). All procedures were performed successfully without any complications. In the early postoperative period, the result indicated a clear graft (Figure 3E).

The UCVA was improved in 11 eyes (78.6\%) after surgery. The treated eyes gained 1.7 lines (range, unchanged to 6 lines) postoperatively. All treated eyes gained 2.4 lines (range, 1-8 lines) in BCVA after surgery. For ECD the value was $2041.58 \pm 529.32$ cells $/ \mathrm{mm}^{2}$ (range, 1016.63104.6 cells $/ \mathrm{mm}^{2}$ ), there was $3.7 \%$ loss compared with preoperatively. We have performed phototherapeutic keratectomy (PTK; $80 \mu \mathrm{m}$ of thickness) to treat residual corneal scar in three eyes (Figure $3 \mathrm{C}$ ). We have removed the suture at 1.25 months of follow-up (Figure 3F).

\section{Discussion}

Femtosecond laser assisted lamellar keratoplasty [10-12] has been reported to be successful in treatment of eyes with stromal corneal pathology. Yoo et al. [11] reported IntraLase femtosecond laser-assisted sutureless anterior lamellar keratoplasty with cut 160 to $270 \mu \mathrm{m}$ of recipient stromal thickness. In their study, there were 7 eyes (58.3\%) improved UCVA, however it didn't improve the BCVA in all treated eyes. In our study, we have performed ALK with 500-kHz VisuMax femtosecond laser. The mean recipient stromal cut thickness was $374.29 \pm$ $80.07 \mu \mathrm{m}$ (range, 190-500 $\mu \mathrm{m}$ ). Eleven eyes $(78.6 \%)$ and all treated eyes got improved UCVA and BCVA respectively after surgery without intraoperative complications. All grafts were successfully created in donor and recipient corneas. No graft rejection was observed during the follow-up period. Almousa et al. [13] reported that 5 out of 20 grafts were rejected, with one case of epithelial ingrowth and infection also occurring, with mean follow-up time of $42 \pm 15$ (7-58) months. While there

Table 1 Patient characteristics and post-ALK outcomes

\begin{tabular}{|c|c|c|c|c|c|c|c|c|}
\hline Patient & $\begin{array}{l}\text { Gender/ } \\
\text { Age }\end{array}$ & Diagnosis & $\begin{array}{l}\text { Preoperative } \\
\text { UCVA/BCVA }\end{array}$ & $\begin{array}{l}\text { Postoperative } \\
\text { UCVA/BCVA }\end{array}$ & $\begin{array}{l}\text { Preop } \\
\text { keratometric } \\
\text { cylinder (D) }\end{array}$ & $\begin{array}{l}\text { Postpo } \\
\text { keratometric } \\
\text { cylinder (D) }\end{array}$ & $\begin{array}{l}\text { Follow-up } \\
\text { (mo) }\end{array}$ & $\begin{array}{l}\text { Time of suture } \\
\text { removal (mo) }\end{array}$ \\
\hline 1 & $M / 40-45$ & $\begin{array}{l}\text { Corneal } \\
\text { scaring }\end{array}$ & $\mathrm{CF} / \mathrm{CF}$ & $\begin{array}{l}0.3 / 0.4 \\
\left(-1.50 \mathrm{DC} \times 120^{\circ}\right)\end{array}$ & 2.15 & 1.65 & 14 & 1.25 \\
\hline 2 & $F / 65-70$ & $\begin{array}{l}\text { Corneal } \\
\text { leucoma }\end{array}$ & $\mathrm{CF} / \mathrm{CF}$ & $\begin{array}{l}0.12 / 0.15 \\
\left(-2.00 \mathrm{DC} \times 150^{\circ}\right)\end{array}$ & 2.49 & 1.87 & 12 & Selective \\
\hline 3 & M/35-40 & $\begin{array}{l}\text { Corneal } \\
\text { leucoma }\end{array}$ & $\begin{array}{l}0.12 / 0.25 \\
\left(-6.0 \mathrm{DC} \times 120^{\circ}\right)\end{array}$ & $\begin{array}{l}0.25 / 0.4 \\
\left(+3.0 \mathrm{DS} /-6.0 \mathrm{DC} \times 140^{\circ}\right)\end{array}$ & 6 & 4.7 & 10 & Selective \\
\hline 4 & M/20-25 & $\begin{array}{l}\text { Corneal } \\
\text { leucoma }\end{array}$ & $0.12 / 0.12$ & $0.3 / 0.4(+1.5 \mathrm{DS})$ & 9.24 & 3.46 & 9.5 & Selective \\
\hline 5 & M/60-65 & $\begin{array}{l}\text { Corneal } \\
\text { leucoma }\end{array}$ & $0.08 / 0.08$ & $0.1 / 0.1$ & 7.02 & 3.18 & 10.5 & Selective \\
\hline 6 & M/75-80 & $\begin{array}{l}\text { Corneal } \\
\text { dystrophy }\end{array}$ & $\mathrm{CF} / \mathrm{CF}$ & $0.1 / 0.1$ & 2.55 & 1.5 & 9.5 & 8 \\
\hline 7 & $M / 45-50$ & $\begin{array}{l}\text { Corneal } \\
\text { dystrophy }\end{array}$ & $0.2 / 0.2$ & $\begin{array}{l}0.25 / 0.5 \\
\left(-2.50 \mathrm{DC} \times 125^{\circ}\right)\end{array}$ & 1.95 & 1.83 & 7.5 & In situ \\
\hline 8 & M/50-55 & $\begin{array}{l}\text { Corneal } \\
\text { leucoma }\end{array}$ & $\mathrm{CF} / \mathrm{CF}$ & $\begin{array}{l}0.06 / 0.1 \\
\left(-4.0 \mathrm{DC} \times 105^{\circ}\right)\end{array}$ & 1.92 & 1.9 & 7.5 & Selective \\
\hline 9 & $F / 60-65$ & $\begin{array}{l}\text { Corneal } \\
\text { leucoma }\end{array}$ & $\mathrm{CF} / \mathrm{CF}$ & 0.1/0.12(pinhole) & 5.85 & 4.66 & 5.5 & Selective \\
\hline 10 & $F / 65-70$ & $\begin{array}{l}\text { Corneal } \\
\text { leucoma }\end{array}$ & $0.2 / 0.2$ & $\begin{array}{l}0.2 / 0.25 \\
\left(-2.50 \mathrm{DS} /-6.0 \mathrm{DC} \times 150^{\circ}\right)\end{array}$ & 8.02 & 4.11 & 4.5 & In situ \\
\hline 11 & M/65-70 & $\begin{array}{l}\text { Corneal } \\
\text { leucoma }\end{array}$ & $0.12 / 0.12$ & $\begin{array}{l}0.25 / 0.25 \\
\left(-4.00 \mathrm{DC} \times 165^{\circ}\right)\end{array}$ & 2.42 & 1.1 & 5 & In situ \\
\hline 12 & $M / 45-50$ & $\begin{array}{l}\text { Corneal } \\
\text { dystrophy }\end{array}$ & $\begin{array}{l}0.12 / 0.25 \\
(+3.0 \mathrm{DS} /-1.0 \mathrm{DC} \times 140)\end{array}$ & $\begin{array}{l}0.12 / 0.4 \\
\left(-2.00 \mathrm{DC} \times 70^{\circ}\right)\end{array}$ & 1.36 & 1.37 & 2 & In situ \\
\hline 13 & $F / 20-25$ & $\begin{array}{l}\text { Corneal } \\
\text { dystrophy }\end{array}$ & $\begin{array}{l}0.2 / 0.25 \\
\left(-5.0 \mathrm{DC} \times 130^{\circ}\right)\end{array}$ & $\begin{array}{l}0.2 / 0.3 \\
\left(-1.00 \mathrm{DS} /-6.0 \mathrm{DC} \times 150^{\circ}\right)\end{array}$ & 6.84 & 5.85 & 2.5 & 2.5 \\
\hline 14 & $F / 35-40$ & $\begin{array}{l}\text { Corneal } \\
\text { dystrophy }\end{array}$ & $\mathrm{CF} / \mathrm{CF}$ & $0.1 / 0.1$ & 5.17 & 3.56 & 2 & In situ \\
\hline
\end{tabular}

$\mathrm{BCVA}=$ best-corrected visual acuity, $\mathrm{CF}=$ counting fingers, $\mathrm{KC}=$ keratoconus, $\mathrm{PTK}=$ phototherapeutic keratectomy, $\mathrm{UCVA}=$ uncorrected visual acuity. 
was neither epithelial ingrowth nor infection observed in our study. However, 6 of 14 patients had less than 6 months of follow-up time. This was insufficient to adequately assess graft rejection, which is at highest risk up to 1 year.

Additionally, the use of anterior segment optical coherence tomography (used to estimate the depth of corneal scarring) allowed us to accurately perform ALK.

In all patients, lamellar separation was successfully performed despite varying degrees of corneal opacification. The effectiveness of a femtosecond laser for patients with corneal scarring has already been described [14]. In addition, the ability to create a vertical side cut with the femtosecond laser could further improve the fit at the graft-host junction.

There were no late complications during our study's follow-up period. In 3 patients, additional PTK procedures were needed for residual corneal scarring. Before PTK, ultrasound corneal pachymetry was used to evaluate the depth of the residual corneal scarring (Figure 3C).

\section{Conclusions}

The 500-kHz VisuMax femtosecond laser produced an effective and smooth dissection through opaque corneas even at deeper corneal tissues. Graft transplantation was therefore simple and effective.

\section{Competing interests}

The authors declare that they have no competing interests.

\section{Authors' contributions}

$\mathrm{ZH}$ conceived and designed the study. $X \mathrm{C}$ and $\mathrm{LY}$ acquired the data. $Y \mathrm{~L}$ drafted the manuscript. $Y L, L Y, Y G, X C$, and $Z H$ critically revised the manuscript for intellectual content. All authors read and approved the final manuscript.

\section{Acknowledgements}

This work was supported by a National Natural Science Foundation Grant 81270979 and a Jiangsu Province Natural Science Foundation Grant BK2012777. The funding agencies had no role in the study design, the data collection and analyses, the decision to publish, or the preparation of the manuscript.

Received: 18 October 2013 Accepted: 19 February 2015

Published online: 01 March 2015

\section{References}

1. Shimmura S, Tsubota K. Deep anterior lamellar keratoplasty. Curr Opin Ophthalmol. 2006;17:349-55.

2. Vajpayee RB, Tyagi J, Sharma N, Kumar N, Jhanji V, Titiyal JS. Deep anterior lamellar keratoplasty by big-bubble technique for treatment corneal stromal opacities. Am J Ophthalmol. 2007;143:954-7.

3. Anwar M, Teichmann KD. Deep lamellar keratoplasty surgical techniques for anterior lamellar keratoplasty with and without baring of Descemet's membrane. Cornea. 2002;21:374-83.

4. Parthasarathy A, Tan DTH. Deep anterior lamellar keratoplasty for keratoconus [letter]. Cornea. 2007;26:1025.

5. Villarrubia A, Pérez-Santonja JJ, Palacín E, Rodríguez-Ausín PP, Hidalgo A. Deep anterior lamellar keratoplasty in post-laser in situ keratomileusis keratectasia. J Cataract Refract Surg. 2007;33:773-8.

6. Park K-A, Ki C-S, Chung E-S, Chung T-Y. Deep anterior lamellar keratoplasty in Korean patients with Avellino dystrophy. Cornea. 2007;26:1132-5.
7. Parthasarathy A, Tan DTH. Deep lamellar keratoplasty for Acanthamoeba keratitis. Cornea. 2007;26:1021-3.

8. Susiyanti M, Mehta JS, Tan DT. Bilateral deep anterior lamellar keratoplasty for the management of bilateral post-LASIK mycobacterial keratitis. J Cataract Refract Surg. 2007;33:1641-3.

9. Buratto L, Belloni S, Valeri R. Excimer laser lamellar keratoplasty of augmented thickness for keratoconus. J Refract Surg. 1998;14:517-25.

10. Hoffart L, Proust H, Matonti F, Catanèse M, Conrath J, Ridings B. Femtosecond-assisted anterior lamellar keratoplasty. J Fr Ophthal. 2007;30:689-94.

11. Yoo SH, Kymionis GD, Koreishi A, Ide T, Goldman D, Karp CL, et al. Femtosecond laser-assisted sutureless anteriorlamellar keratoplasty. Ophthalmology. 2008;115:1303-7.

12. Agarwal A, Brubaker JW, Mamalis N, Kumar DA, Jacob S, Chinnamuthu S, et al. Femtosecond-assisted lamellar keratoplasty in atypical Avellino corneal dystrophyof Indian origin. Eye Contact Lens. 2009;35:272-4.

13. Almousa R, Samaras KE, Khan S, Lake DB, Daya SM. Femtosecond laserassisted lamellar keratoplasty (FSLK) for anterior corneal stromal diseases. Int Ophthalmol. 2014;34:49-58.

14. Muñoz G, Albarrán-Diego C, Sakla HF, Pérez-Santonja JJ, Alió JL. Femtosecond laser in situ keratomileusis after radial keratectomy. J Cataract Refract Surg. 2006;32:1270-5.

\section{Submit your next manuscript to BioMed Central and take full advantage of:}

- Convenient online submission

- Thorough peer review

- No space constraints or color figure charges

- Immediate publication on acceptance

- Inclusion in PubMed, CAS, Scopus and Google Scholar

- Research which is freely available for redistribution 